\title{
Foreign Postgraduate Students in Soviet and Russian Higher Education Institutions: The Statistical and Sociological Analysis
}

\author{
Alexander Aref'ev \\ PhD, Deputy Director for Science of the Center for Sociological Research of the Ministry of Education and the \\ Science of the Russian Federation; E-mail: alexander.arefiev@gmail.com \\ Irina Trostyanskaya \\ PhDr., Leading Researcher of the Center for Sociological Research of the Ministry of Education and the \\ Science of the Russian Federation; E-mail: i.trostyanskaya@mail.ru
}

\section{Doi:10.5901/mjss.2015.v6n5s4p124}

\section{Abstract}

\begin{abstract}
The article highlights the trends in training the personnel of the highest qualification for foreign countries in Soviet and Russian higher education institutions: the change in the number of foreign postgraduate students and their contingent according to the countries of origin, the majors that they studied in the Soviet times and now, as well as the sources of information and motivation of postgraduate training in Russian higher education institutions, the major problems (difficulties) of adaptive nature, which they faced during the first weeks and months after their arrival for training, the satisfaction with the living conditions in Russia and with the quality of training in postgraduate centers. The article provides data on the cost of their training and the amount of the daily residential expenses; analyzes the social and professional plans of the foreign postgraduate students trained in Russia; and suggests information on the sociodemographic contingent of the foreign postgraduate students. The authors conclude on certain achievements in training highly qualified personnel for foreign countries in Russian higher education institutions over the last decade (on the growing number of foreign postgraduate students, on the increasing percentage of students satisfied with the quality of training, and on more tolerant attitude of the Russians to foreign students), but at the same time, they point out a number of persistent problems, including the poor knowledge of the Russian language by almost half of the postgraduate students, which hinders their comprehensive study, the significant percentage of students unsatisfied with the social conditions, as well as of those who wary of meeting difficulties with the future employment having a Russian diploma. The article was prepared based on the departmental statistics of the Ministry of Education of the USSR and the Ministry of Education and Science of the Russian Federation, as well as on the sociological polls among foreign postgraduate students of Russian higher education institutions, which were conducted by the Center for Sociological Research in the academic years of 2004/2005 and 2014/2015 (the research advisor was A.L. Aref'ev).
\end{abstract}

Keywords: Russian higher education institutions, foreign postgraduate students, training.

\section{Introduction}

Training of the highly qualified personnel within the postgraduate system of Russian higher education institutions is the most challenging and prestigious form of educational services provided to foreign citizens, and at the same time, it is an indicator of the scientific and pedagogical potential of the Russian higher education, and the prestige of the Russian science abroad.

In the USSR, it was prestigious to complete the postgraduate studies and to obtain the Soviet diploma of a Candidate of Sciences, as the Soviet system of education and the research training were considered ones of the best in the world, and the Soviet diploma of a Candidate or Doctor of Sciences contributed to the career development of its owners in many countries of the Eastern Europe, Asia, Africa, and Latin America. The system of training highly qualified personnel for foreign countries was continuously improved. Foreign postgraduate students studied in the leading higher education institutions with a good laboratory, research, and development base, as well as in academic institutes and in discipline-specific research institutes. They were provided with everything they needed: dormitories, scholarships, academic and scientific literature, highly qualified supervisors, etc. The preference in enrollment to the postgraduate centers of the foreign citizens was given to the graduates of the Soviet higher education institutions, since they had a good command of Russian language and were adequately trained within the field of their specialization. In the 1980s, foreign postgraduate students accounted for nearly one tenth of all categories of the foreign students receiving the Soviet 
higher education.

After the collapse of the Soviet Union, the centralized system of enrollment, training, and arrangement of the production practices and the scientific fellowships for the foreign citizens was destroyed. Simultaneously, the number of higher education institutions sharply increased including private institutions entitled to independently enroll foreign students to relevant academic programs. What was the impact of these changes on the quantitative and qualitative indicators of training the foreign postgraduate students, what are the main challenges currently met by these students? This article aims to answer these and many other pressing questions related to the training of foreign postgraduate students through the analysis of the educational statistics and the results of the sociological researches.

\section{Literature Review}

The topic related to the study of foreign postgraduates in Russia has been poorly developed by the scientific literature. In the USSR, due to the isolation of the society, the information concerning foreign citizens was either not published at all or was published under the heading "For Official Use Only". With regard to the USSR period and to the first 10 years of the post-Soviet period, the topic about foreign postgraduates as one of the categories of foreign students is to a certain extent covered by the collection of informational, analytical, and methodological materials prepared by the staff of the Department of International Cooperation and the Department of Specialists Training for Foreign Countries of the Ministry of Education of Russia (Obuchenie inostrannykh grazhdan v vysshikh uchebnykh zavedeniiakh Rossiiskoi Federatsii [Training of foreign citizens at higher education institutions of the Russian Federation], 1999), in the monographs Nauchno-pedagogicheskii potentsial i eksport rossiiskikh obrazovatel'nykh uslug rossiiskikh vuzov [The Scientific and Pedagogical Potential and the Export of the Russian Educational Services of the Russian Higher Education Institutions] (Sheregi, 2002), Podgotovka kadrov dlia zarubezhnykh stran v sovetskikh vuzakh [Training of personnel for the foreign countries in Soviet higher educational institutions] (Belov, 2000), Obuchenie inostrannykh grazhdan v Rossii: Istoricheskii opyt, problemy, perspektivy [Training of foreign citizens in Russia: historical experience, problems, and prospects] (Belov, 2003), and in a number of scientific articles (e.g., Golubev, 1994).

The lack of reliable and available statistics on foreign postgraduate students in Russian higher education institutions also hampered the comprehensive analysis of the trends in the problems of academic training faced by the given category of the foreign citizens during the post-Soviet period. None of the official statistical publications including "Rossiiskii statisticheskii ezhegodnik" [Russian Statistical Yearbook] issued by the Federal Service of State Statistics or "Obrazovanie v Rossiiskoi Federatsii" [Education in the Russian Federation] issued by the Higher School of Economics together with the Federal Service of State Statistics) contains the data on foreign postgraduate students, though they provide information on the foreign students studying at state higher education institutions.

The issues concerning the academic training of the foreign postgraduate students in Russia were only covered in the collections of normative documents (The Reference and Methodological Guide, 2006; The Russian Education for the Foreign Citizens, 2010), and were also addressed in connection with the coverage of the foreign countries' experience in rendering educational services to foreign citizens including doctoral programs (Tkach and Filippov, 2014). At the same time, in a number of specialized works devoted to the export of the Russian educational services and the calculation of their value indicators, foreign postgraduates as one of the categories of foreign students were not taken into account at all (Beliakov et al., 2011).

Since 2003, the systematized statistical data on the foreign postgraduates studying at Russian higher education institutions have started to be regularly published in the Departmental Statistics Digest "Obuchenie inostrannykh grazhdan v vysshikh uchebnykh zavedeniiakh Rossiiskoi Federatsii" (Training of Foreign Citizens, 2015). It contained generalized data on the number of foreign full-time postgraduate students of Russian education institutions of various types and education-scientific profiles, of different departmental belongings and ownerships, and also located in various federal districts and types of settlements, etc. Since 2007, the more fundamental statistics digest on the full-time and parttime forms of training of foreign citizens at Russian higher and secondary professional education institutions and in their foreign branches started to be published, which provided the number of foreign postgraduate students according to each Russian higher education institution, the specialties studied by the foreign postgraduates, as well as the calculations of the income value obtained from their training (Eksport rossiiskikh obrazovatel'nykh uslug [Export of the Russian Educational Services], 2015). During this period, the first specialized works were published, which were devoted to foreign postgraduate students in Russia, such as Podgotovka kadrov vysshei kvalifikatsii v rossiiskikh vuzakh [Training of Highly Qualified Personnel at Russian Higher Education Institutions] (Aref'ev, 2004). The indicators of the academic training of the foreign postgraduate students began to appear in the collective monographs on the Russian education (Modernizatsiia rossiiskogo obrazovaniia: problemy i perspektivy [Modernization of the Russian education: problems and 
prospects], 2010), and on the international education (Izmerenie reitingov universitetov. Mezhdunarodnyi i rossiiskii opyt [Measuring the university rankings. International and Russian experience], 2014). At the same time, the actual challenges and trends as well as the prospects of training of foreign postgraduates at Russian higher education institutions have not yet been adequately covered by the scientific literature.

\section{The Purpose, Objectives, and Methods of the Research}

The purpose of the article is to identify the main trends in training the highly qualified personnel for foreign countries at postgraduate centers of the RSFSR and the Russian Federation.

The objectives of the study are as follows:

- the analysis of the change in the total number and contingent of foreign postgraduate students by countries of origin at Russian higher education institutions during the Soviet and the post-Soviet periods;

- the comparative analysis of the major specializations of foreign postgraduate students during the Soviet and the postSoviet periods;

- the identification of the sources of information and motives of studying at the postgraduate centers of Russian higher education institutions;

- the identification of the main challenges of academic training faced by foreign postgraduate students at the current stage including the degree of their satisfaction with the training received at Russian higher education institutions and with the conditions of living in Russia during the period of training;

- the identification of the plans of foreign postgraduate students after completing the Russian postgraduate study for the employment in various countries, and the percentage of students who desire to further work and live in Russia;

- the forecast of the number of foreign postgraduate students at Russian higher education institutions for the period until 2030.

This study was based on the archive data of the departmental statistics of the Ministry of Education of the USSR, as well as the departmental statistics on the academic training of all categories of foreign citizens including foreign postgraduate students, which is collected by the Center of Sociological Research of the Ministry of Education and Science of the Russian Federation.

To identify the sources of information and the motives of studying at the postgraduate centers of Russian higher education institutions, the degree of satisfaction with the received professional training, and with the everyday living conditions, the problems related thereto, as well as the further professional and life plans of foreign graduates of Russian postgraduate centers, the authors used the results of the polls conducted among foreign postgraduates according to the representative sampling in 2005 (397 postgraduates from 68 countries were interrogated), and in 2015 (306 postgraduates from 59 countries were interrogated) by the Center of Sociological Research of the Ministry of Education and Science of the Russian Federation (in total, 537 foreign postgraduate students were interrogated; the research coordinator was A.L. Aref'ev).

\section{Analysis of the Statistics}

Training of highly qualified personnel within the postgraduate system of Russian higher education institutions is the most challenging and prestigious form of educational services provided to foreign citizens, and at the same time, is an indicator of the scientific and pedagogical potential of the Russian higher education and the prestige of the Russian science abroad.

Over the past 10 years, the number of full-time foreign postgraduate students enrolled to Russian higher education institutions ${ }^{1}$ has increased by two thousand people (Figure 1).

\footnotetext{
${ }_{1}^{1}$ The number of foreign postgraduates currently attending the part-time course of study is less than 500 people.
} 


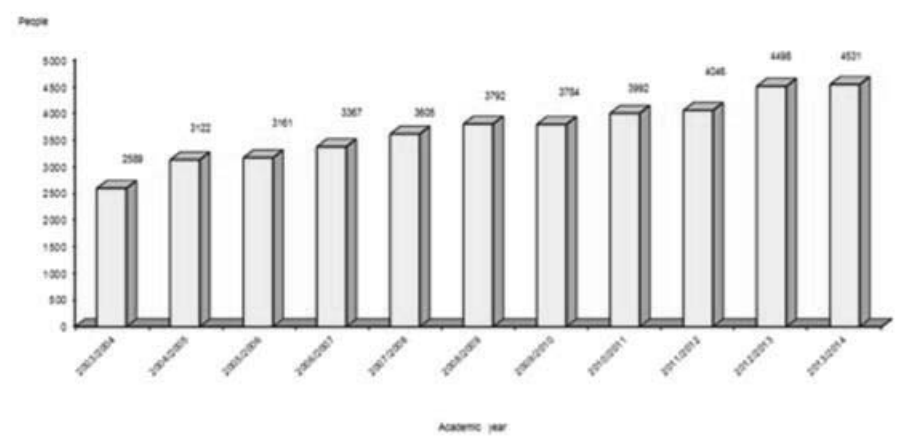

Figure 1. The change in the number of full-time foreign postgraduates studying at Russian higher education institutions in the academic years of 2003/2004 - 2013/2014.

However, the percentage of foreign postgraduate students in the total number of foreign citizens studying at Russian education institutions on the full-time basis has been steadily declining since the late 1990s (Table 1).

Table 1. The dynamics of the percentage of foreign postgraduates in the total number of foreign citizens studying at Russian education institutions on the full-time basis $s$ in the academic years of 1998/1999 - 2013/2014.

\begin{tabular}{|c|c|c|c|}
\hline Years & $\begin{array}{l}\text { The total number of foreign } \\
\text { citizens studying at Russian } \\
\text { education institutions on the } \\
\text { full-time basis }\end{array}$ & $\begin{array}{l}\text { The number of the foreign } \\
\text { postgraduates studying at } \\
\text { Russian education institutions } \\
\text { on the full-time basis }\end{array}$ & $\begin{array}{l}\text { The percentage of foreign postgraduate } \\
\text { students in the total number of foreign } \\
\text { citizens studying at Russian education } \\
\text { institutions on the full-time basis, \% }\end{array}$ \\
\hline $1998 / 1999$ & 61,317 & 3,156 & 5.1 \\
\hline $1999 / 2000$ & 57,907 & 2,902 & 5.0 \\
\hline $2000 / 2001$ & 53,918 & 2,440 & 4.5 \\
\hline $2001 / 2002$ & 60,674 & 2,505 & 4.2 \\
\hline $2002 / 2003$ & 64,341 & 3,282 & 5.1 \\
\hline $2003 / 2004$ & 67,784 & 2,589 & 3.8 \\
\hline $2004 / 2005$ & 82,250 & 3,114 & 3.8 \\
\hline $2005 / 2006$ & 86,875 & 3,161 & 3.6 \\
\hline $2006 / 2007$ & 93,742 & 3,367 & 3.6 \\
\hline $2007 / 2008$ & 101,182 & 3,605 & 3.6 \\
\hline $2008 / 2009$ & 108,565 & 3,792 & 3.5 \\
\hline $2009 / 2010$ & 108,084 & 3,784 & 3.5 \\
\hline $2010 / 2011$ & 118,730 & 3,992 & 3.4 \\
\hline $2011 / 2012$ & 125,538 & 4,046 & 3.2 \\
\hline $2012 / 2013$ & 139,578 & 4,498 & 3.2 \\
\hline $2013 / 2014$ & 156,211 & 4,531 & 2.9 \\
\hline
\end{tabular}

If we also take into account the part-time form of academic education, in which in the academic year 2013/2014 about 500 foreign citizens were studying, their share in the total number of all foreign students, trainees, postgraduates, participants of the preparatory courses, etc. of both the full-time (156,211 persons) and part-time (94,040 persons) form of academic education will only amount to $2 \%$.

As a comparison, it can be noted that during the USSR period, the percentage of full-time and part-time postgraduate students in the total number of foreign students studying in Russian higher education institutions (the RSFSR higher education institutions) was significantly higher. For example, among all foreign graduates of Russian higher education institutions, who studied during the academic period from 1980/1981 to 1989/1990 in various programs (certified specialists, masters, registrars, postgraduates, doctoral students, as well as participants of preparatory courses and trainees, including the advanced training courses), the percentage of the postgraduate students amounted to $9.3 \%$ (7,174 persons in the total number of graduates of 77,389 persons). It is characteristic that in the Soviet time, almost all foreign citizens were enrolled to the full-time study, while the number of foreign off-campus students at RSFSR higher 
education institutions (779 persons among all the graduates of the years 1980/81-1989/90) was significantly lower, than of the foreign postgraduates $(1,100$ foreigners who completed the part-time courses of the postgraduate study in the 1980s).

For the citizens of many countries, it was prestigious to complete the postgraduate course of study in the USSR, since the Soviet system of the scientific personnel training was considered one of the best in the world, and the Soviet Union was among the group of countries leading in the crucial fields of science and technology. Suffice it to say that still in the late 1980s, a quarter of all the world inventions fell to the share of the Soviet science (in 1987, the USSR filed applications for 83,700 patents, the USA - only 82,900, Japan - 62,400, and Germany and England - 28,700 patents) (Fiull'zak, 2001).

During the post-war period, foreign postgraduate students were provided with the arrangement of a 6-month preparatory course of study of the Russian language and profession-related subjects, the completion of which was accompanied by the exam in the Russian language and by the interview on the specialty, and the total period of the fulltime postgraduate study reached 3.5 years. In the early 1980 s, the duration of the preparatory course was gradually increasing: it included the practice of enrolling foreign candidates for the postgraduate studies to the 10-month preparatory fellowship. The foreigners were allowed to pass the candidate examinations during the entire academic year, and their theses were accepted for defense without waiting in line and without publication of their fundamental principles. Due to this, the majority of the foreign citizens completed the postgraduate course of study with the defense of theses, while among the Russian postgraduates the percentage of students, who managed to defend their theses, in the academic year $1989 / 1990$ amounted to $26.0 \%$ in the postgraduate centers of higher educational institutions, and even less-13.2\%—in the postgraduate centers of research institutes (that also enrolled foreign students).

While in the 1950-1960s, the groups of foreign postgraduate students were dominated by the representatives of the Eastern European socialists countries, since the early 1970s and especially in the 1980s, the percentage of students coming from the Arab countries, Asia, Africa, and Latin America significantly increased (Figure 2), which was associated with the emergence of new independent states being in dire need of highly qualified professionals.

In general during the 1980s, the postgraduate course of study in RSFSR higher education institutions was completed by the representatives of almost 100 countries, among which the leading countries of Eastern Europe were Poland (400 persons), Bulgaria (401 persons), and Czechoslovakia (125 persons); the leading Asian countries were represented by Vietnam (660 persons), India (160 persons), and the Democratic People's Republic of Korea (121 persons); among the Arab countries, the greatest number of postgraduate students mainly came from Syria (657 persons), Algeria (248 persons), and Egypt (202 persons); the African countries were represented by Guinea (142 persons), Mali (109 persons), and Nigeria (84 persons); and more than half of all the Latin American postgraduate students were the natives from Cuba (named in the USSR as the "Island of Liberty") (360 persons). As a rule, the greatest numbers of the postgraduate students belonged to the socialist countries, which were allied to the USSR, and to the Afro-Asian countries of the so-called socialist orientation.

The postgraduate students who completed the part-time postgraduate course of study at RSFSR higher education institutions during the academic period of 1980/1981 - 1989/1990 were mainly represented by the students from the former socialist countries, such as Poland (172 persons), Bulgaria (144 persons), Czechoslovakia (116 persons), Hungary (102 persons), the German Democratic Republic (102 persons), and Cuba (217 persons).

The foreign postgraduate students studied in 428 programs, which covered all fields of knowledge, including such progressive for that time subjects as biochemistry, biophysics, mathematical cybernetics, physical electronics, physical chemistry, technical cybernetics and information theory, nuclear physics, etc. (Figure 3). But simultaneously, starting from the academic year 1969/1970, the compulsory study of the Marxist-Leninist philosophy was also introduced. 




Figure 2. The percentage of foreign postgraduates graduated from RSFSR higher education institutions in the academic years 1980/1981-1989/1990 by countries of origin, $\%$.

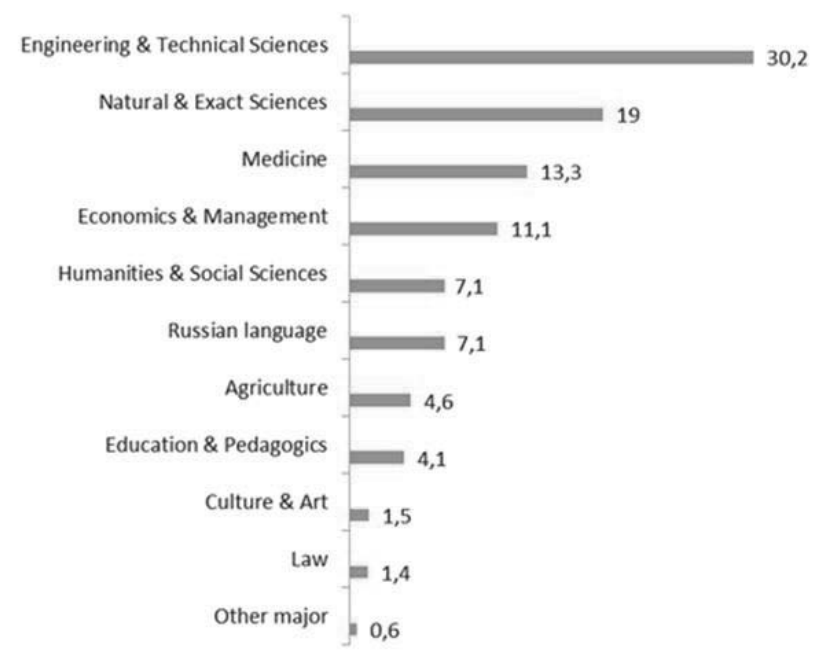

Figure 3. The main groups of majors studied by foreign postgraduate students at higher education institutions of the RSFSR in the academic years of 1980/1981 - 1989/1990, \%.

Of course, the postgraduate students from different countries preferred different sciences. For example, the USA representatives, who studied in the Soviet postgraduate centers, favored the humanities - almost every second American postgraduate student studied them, wherein the majority of them studied and collected materials on the history of the Communist Party of the Soviet Union (CPSU) (112 persons or 35.7\% of postgraduate students), the rest specialized in the world history (16 persons), ethnography (7 persons), archeology (3 persons), history of philosophy (2 persons), and psychology (1 person). The second most important specialty among the American postgraduate students was the Russian and Soviet multinational literature, the third-the Russian language, the Slavic languages, and the languages of the USSR peoples. It is also interesting that within the framework of the economic majors, several persons studied political economy, i.e. the economic theory of Marxism (Table 2). 
Table 2. The majors studied by the American postgraduate students (with the training period of more than 6 months) at Soviet higher educational institutions in 1962-1992.

\begin{tabular}{|l|c|c|}
\hline Academic majors & The number of students, persons & Percentage of students, \% \\
\hline Humanities & 149 & 47.5 \\
\hline Russian literature and multinational Soviet literature & 84 & 26.7 \\
\hline $\begin{array}{l}\text { The Russian language, the Slavic languages, and the } \\
\text { languages of the USSR peoples }\end{array}$ & 45 & 14.3 \\
\hline Law & 14 & 4.4 \\
\hline Economic sciences & 7 & 2.2 \\
\hline Art & 5 & 1.6 \\
\hline Natural and exact sciences & 4 & 1.3 \\
\hline Engineering and technical sciences & 3 & 1.0 \\
\hline Medicine & 3 & 1.0 \\
\hline Total & 314 & 100.0 \\
\hline
\end{tabular}

The American postgraduate students studied the Russian language and literature mainly at the Leningrad State University, while they preferred to study the languages of the USSR peoples and the Soviet national literature at higher education institutions of the national republics of the USSR (Armenia, Belarus, Lithuania, Ukraine, Uzbekistan, and Tajikistan), as well as at higher education institutions of a number of national autonomous regions of the country (the Tatar ASSR, the Chuvash ASSR, etc.). Such an opportunity appeared in the 1980s-early 1990s.

During the Soviet period, the majority of foreign postgraduate students studied at higher education institutions of Moscow and Leningrad (Table 3).

Table 3. The higher education institutions of the RSFSR-leaders in the number of foreign postgraduate students trained therein during the academic years of 1980/1981 - 1989/1990.

\begin{tabular}{|l|c|}
\hline Higher education institutions & The number of foreign postgraduate students \\
\hline 1. The Lomonosov Moscow State University & 1,009 \\
\hline 2. The Leningrad State University & 401 \\
\hline 3. The People's Friendship University of Russia & 256 \\
\hline 4. The Leningrad State Polytechnic University & 231 \\
\hline 5. The Gubkin Russian State Oil and Gas University & 249 \\
\hline 6. The Moscow Agricultural Academy named after K.A. Timiryazev & 190 \\
\hline 7. The Moscow D. Mendeleev Institute of Chemical Technology & 151 \\
\hline 8. The Plekhanov Russian University of Economics & 148 \\
\hline 9. The Moscow Power Engineering Institute & 147 \\
\hline 10. The Moscow Automobile and Road Construction University & 142 \\
\hline 11. The Leading Saint Petersburg State Electrotechnical University named after & 139 \\
\hline V.I. Ulyanov (Lenin) & \\
\hline 12. The State Central Order of Lenin Institute of Physical Education & 119 \\
\hline 13. The Moscow Institute of Civil Engineering & 116 \\
\hline 14. The Leningrad Institute of Finance and Economics & 108 \\
\hline 15. The Moscow Institute for Steel and Alloys & 104 \\
\hline
\end{tabular}

The main changes after the collapse of the Soviet Union in the field of academic training of the foreign postgraduate students related not only to the reduction of their number at Russian higher education institutions, but also to the contingent of the postgraduate students by the countries of origin and the majors studied.

Currently, foreign postgraduate students of Russian higher education institutions are basically represented only by two groups of countries (regions)-Asia and the former USSR national republics (primarily, the CIS countries). AS compared to the Soviet period, the representatives of the Eastern European and Latin American countries demonstrated the most noticeable reduction in number (Figure 4). 


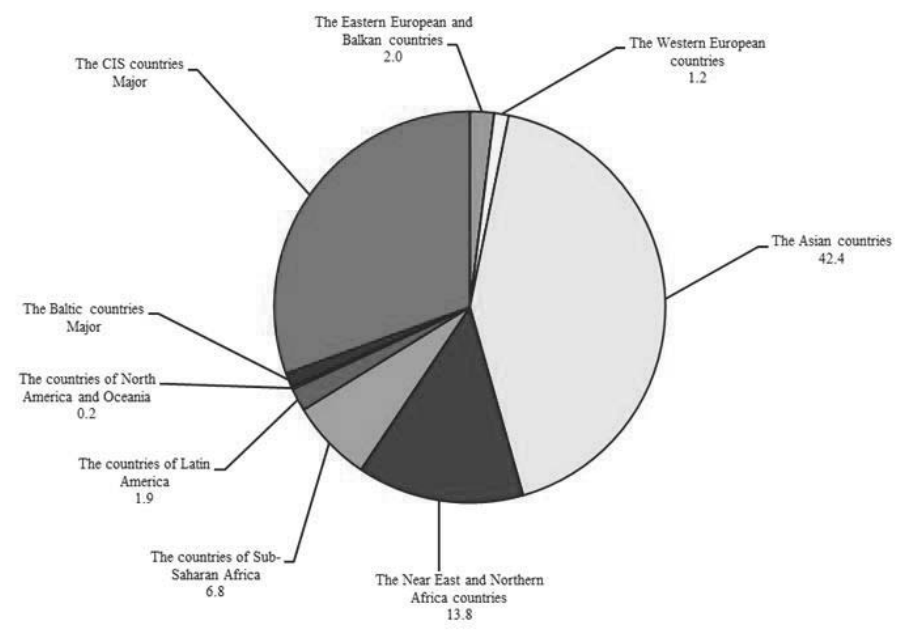

Figure 4. The percentage of full-time foreign postgraduates studying at postgraduate centers of Russian higher education institutions in the academic year 2013/2014 by countries of origin, $\%$.

The largest group of the postgraduate students from the CIS countries is represented by the natives of Kazakhstan (343 persons) and Ukraine (169 persons), and the smallest group—by the natives of Georgia (34 persons), Turkmenistan (29 persons), Abkhazia (29 persons), and South Ossetia (10 persons). Not so many postgraduate students come from the Baltic States (in general, 53 persons).

Among the Eastern European countries, there is no country, the number of postgraduate students from which would exceed 20 persons. The same situation concerns the countries of the Western Europe.

The great changes occurred in the contingent of postgraduate students from the Asian countries. Currently, the leader in the number of postgraduate students is China (623 persons), and still many postgraduates come from Vietnam (554 persons). During the 2000s, the number of postgraduate students from Myanmar (up to 209 persons) and Iran (up to 152 persons) sharply increased, the postgraduates came from South Korea (55 persons), as well as from North Korea. Laos, and Afghanistan have almost stopped sending their citizens to study at Russian postgraduate centers.

Among the Arab countries, the biggest number of postgraduate students currently comes from Iraq (204 persons) and Yemen (115 persons), while the number of Syrian postgraduate students (who earlier dominated among the contingent of natives from this region studying at Russian postgraduate centers) has decreased by 7.3 times as compared to the late 1980s (from 657 to 90 persons).

During the given period, the number of postgraduate students from Africa has also decreased by 2.6 times (from 828 to 310 persons). The number of countries that they represent has decreased by nearly a quarter (from 37 to 30 ). The most noticeable reduction in the contingent occurred in the postgraduate students from Guinea and Mali (earlier, these French-speaking countries were the leaders in the number of citizens sent to Russian postgraduate centers-up to 50 persons per year, while in the recent years, only 3-5 persons come from these countries to study in the Russian postgraduate training programs). The largest contingent of the postgraduates in the academic year 2013/2014 were the natives from Côte d'Ivoire (the Ivory Coast, 48 persons) and Nigeria (41 persons), the population of which (over 180 million persons) significantly exceeds the population of Russia.

The representatives of Latin America are almost unnoticeable among the foreign postgraduate students. Their total number, which has earlier exceeded 500 persons, has currently reduced to 86 persons mainly due to Cuba, the relations with which in all spheres including education were sharply rolled back after the collapse of the Soviet Union. Today, only one postgraduate student from Cuba studies in Russia; and the maximum number of the Latin Americans studying at Russian postgraduate centers is from Ecuador (21 persons). The number of countries from this region, which send their 
citizens to study in the postgraduate programs at Russian higher education institutions, has decreased by $1 / 3$ as compared to 1990.

The countries of North America and Oceania are represented at the Russian postgraduate centers of higher education only by 9 citizens of the USA studying the Russian language, Russian culture, history, and politics.

While almost all foreign postgraduate students studied free of charge during the USSR period, nowadays, $42.3 \%$ of them are trained under a contract. The rest of the students do not pay for the Russian postgraduate program. The reason for this is the enrollment to study on a quota basis (at the expense of the federal budget, as the Russian government scholarship holders) or the training on a grant basis within the framework of the inter-institutional agreements on academic exchanges, or this may be the students enrolled to the state-funded place on the same common grounds as the citizens of Russia (the natives from a number of CIS countries possess this right).

According to Figure 5, the biggest number of the foreign postgraduate students enrolled on a contract basis is from the Asian countries, and the largest number of the postgraduate students paying the minimal fee for their study is from the Baltic and Eastern Europe countries (Figure 5).

It should be noted that the foreign citizens enrolled in the postgraduate programs enjoy the greatest financial benefits compared to other foreigners studying on other academic programs. Suffice it to say that the total share of the foreign students, trainees, interns, registrars, etc. that studied on a full-time contract basis in the Russian higher education institutions during the academic year 2013/2014 (almost 100\% of them study part-time on a contract basis) amounted to $63.7 \%$, i.e. it was by $1 / 3$ lower than among the foreign postgraduate students, and also significantly lower than among the citizens of the Russian Federation.

The representatives of which countries pay the least for the Russian postgraduate programs? Among the CIS countries, the free education is provided to $100 \%$ of postgraduate students from Abkhazia and South Ossetia, and to 80\%-from Turkmenistan. Among the few (and sometimes single) postgraduate students from Europe, free education is provided for the representatives of Malta, Norway, and Switzerland; 7 of 9 postgraduates from Germany study free of charge, as well as 3 of 4 postgraduates from Spain, etc. The same situation occurs among the postgraduate students from Latin America, the Arab East, and Africa. In particular, the share of the Côte d'Ivoire citizens (this country exports to Russia the largest number of the postgraduate students from the Dark Continent) studying on a free basis amounts to $60 \%$. A certain contrast is the situation with the postgraduate students from the Asian countries. For example, just $16.4 \%$ out of 521 postgraduates from China receive free education, as well as $23.0 \%$ out of 269 Vietnamese postgraduates, and only to two persons (1\%) out of 209 postgraduate students from Myanmar.



Figure 5. The percentage of postgraduates from various countries who studied on a contract basis at Russian higher education institutions in the academic year of 2013/2014, \%. 
The measures on attracting foreign citizens to the Russian postgraduate study with the help of granting the abovementioned government scholarships for free training on a quota basis for the various countries cannot be considered the sufficiently consistent and effective ones. If we analyze the statistics on the provision of government scholarships for the academic period of 2011/2012 - 2013/2014, we can notice certain changes in the number and share of government scholarships by groups of countries and regions (Table 4).

Table 4. The indicators of the government scholarship distribution for postgraduate and doctoral students ${ }^{2}$ during the academic years of 2011/2012 - 2013/2014 by groups of countries and regions.

\begin{tabular}{|l|c|c|c|c|c|c|}
\hline \multirow{3}{*}{ Groups of countries / regions } & \multicolumn{2}{|c|}{ Years } & \multicolumn{2}{c|}{$2013 / 2014$} \\
\cline { 2 - 7 } & \multicolumn{2}{|c|}{$2011 / 2012$} & \multicolumn{2}{|c|}{$2012 / 2013$} \\
\cline { 2 - 7 } & $\begin{array}{c}\text { Number of } \\
\text { government } \\
\text { scholarships }\end{array}$ & Share, in \% & $\begin{array}{c}\text { Number of } \\
\text { government } \\
\text { scholarships }\end{array}$ & Share, in \% & $\begin{array}{c}\text { Number of } \\
\text { government } \\
\text { scholarships }\end{array}$ & Share, in \% \\
\hline The CIS countries & 217 & 21.9 & 247 & 23.8 & 225 & 29.3 \\
\hline The Baltic countries & 25 & 2.5 & 22 & 2.1 & 9 & 1.2 \\
\hline The Eastern European countries & 60 & 6.1 & 56 & 5.4 & 47 & 6.1 \\
\hline The Northern and Western European countries & 25 & 2.5 & 26 & 2.5 & 13 & 1.7 \\
\hline The Asian countries & 270 & 27.3 & 270 & 26.0 & 198 & 25.8 \\
\hline The countries of the Middle East and Northern Africa & 168 & 17.0 & 180 & 17.4 & 146 & 19.0 \\
\hline The countries of sub-Saharan Africa & 131 & 13.2 & 132 & 12.7 & 75 & 9.8 \\
\hline The countries of Latin America & 83 & 8.4 & 92 & 8.9 & 42 & 5.5 \\
\hline The countries of North America and Oceania & 11 & 1.1 & 12 & 1.2 & 0 & 0.0 \\
\hline Total & 990 & 100.0 & 1037 & 100.0 & 767 & 100.0 \\
\hline
\end{tabular}

A consistent trend in distributing the government scholarships for the foreign postgraduate students can be considered the increase in their percentage for the former Soviet republics. Wherein the government scholarships for the given group of countries are differentiated into two categories: for the compatriots (they obtain up to $60 \%$ of quotes for a relevant country), and for the representatives of the titular nations. In recent years, among the CIS countries, the traditionally largest number of the postgraduate government scholarships has been intended for Moldova and Transnistria (25) as well as for Armenia, Belarus, Tajikistan, Kyrgyzstan, Kazakhstan, and Uzbekistan (20 to each). When allocating the government scholarships to postgraduate students for the academic year 2013/2014, the quotas for the majority of countries were reduced, however, they were retained for Moldova and Transnistria (26), and significantly increased for Belarus (up to 42) and Armenia (up to 30).

Among the countries of Eastern Europe, the biggest and the most consistent quotas for postgraduates are granted to Slovakia (10 per year); among the countries of the Northern and Western Europe - to Norway (5 per year), among the Asian countries - to Vietnam (115 per year), and also to Mongolia (for several years, the quota for the postgraduate students from this country amounted to 50 students, however, in the academic year 2013/2014, it was reduced to 20). Among the countries of the Arab East, the leaders in the number of annual government scholarships are Egypt (50), Yemen (30), Iraq and Palestine (20 per each). In the academic year 2013/2014, the quota for only Palestine was reduced (down to 15 places), whereas the quota for Syria was increased (up to 20 places). For the last 5 years, for certain countries of Sub-Saharan Africa and Latin America (Guinea, Venezuela, Colombia, Nicaragua, and Ecuador) the maximum number of quotas, as a rule, has not exceeded 10.

The more specific situation is observed with the quotas for government scholarships for the countries of North America and Oceania. Due to the fact that the quotas allocated for Canada (5), Australia (1), and New Zealand (1) were not used, in the academic year 2013/2014, the free government scholarships for training on the postgraduate programs (including for the USA) were cancelled. In this regard, it should be noted that not all the government scholarships allocated by Russia to the far abroad countries (and not only by the postgraduate training programs) turn out to be used. In some years, from 10 thousand of government scholarships, up to 500 scholarships for various reasons remained unused (mainly the scholarships granted for the representatives of Asia, Africa, Latin America, and a number of the European countries).

Almost the same as in the Soviet times, the vast majority of the foreign postgraduate students study at higher education institutions of Moscow and Saint Petersburg (64.0\% in the academic year 2013/2014). Accordingly, they are mainly concentrated at higher educational institutions of the Central and North-Western Federal Districts, where the two

2 The number of annual government scholarships for the doctoral students does not exceed 15-20 and is granted almost exclusively by the request of the CIS countries and Mongolia. 
Russian megalopolises are located; and this ratio is changing very slowly in favor of the regional higher educational institutions (Table 5).

Table 5. The assignments of foreign postgraduate students to the higher education institutions of various federal districts in the academic years of 2009/2010 and 2013/2014, \%.

\begin{tabular}{|l|c|c|c|c|}
\hline \multirow{2}{*}{ Federal district } & \multicolumn{2}{|c|}{$2009 / 2010$ academic year } & \multicolumn{2}{c|}{$2013 / 2014$ academic year } \\
\cline { 2 - 5 } & The number of foreign postgraduates & Share in \% & The number of foreign postgraduates & Share in \% \\
\hline The Central FD & 2,525 & 66.7 & 2,726 & 60.2 \\
\hline The Northwestern DF & 636 & 16.8 & 740 & 16.3 \\
\hline The Southern FD & 181 & 4.8 & 260 & 2.5 \\
\hline The North-Caucasian FD & 44 & 1.2 & 47 & 1.0 \\
\hline The Volga FD & 138 & 3.6 & 47 & 6.3 \\
\hline The Ural FD & 29 & 0.8 & 284 & 1.8 \\
\hline The Siberian FD & 210 & 5.5 & 80 & 7.4 \\
\hline The Far East FD & 21 & 0.6 & 336 & 1.3 \\
\hline Total & 3,784 & 100.0 & 58 & 100.0 \\
\hline
\end{tabular}

Over the past 10 years, the share of foreign citizens studying at the postgraduate centers of classical universities has noticeably increased, but it decreased at the pedagogical universities and discipline-specific higher education institutions (Table 6).

Table 6. The percentage of foreign citizens who studied at the postgraduate centers of Russian higher education institutions of various types, $\%$.

\begin{tabular}{|l|c|c|}
\hline The type of a higher education institution & The year 2003/2004 & The year 2013/2014 \\
\hline A classical university & 28.2 & 40.4 \\
\hline A pedagogical university & 6.5 & 4.2 \\
\hline A discipline-specific higher education institution & 65.3 & 55.4 \\
\hline Total & 100.0 & 100.0 \\
\hline
\end{tabular}

The postgraduate centers of the Ministry of Education and Science of Russia and of the state higher education institutions as a whole are of the greatest demand among the foreign citizens wishing to study in Russia in the postgraduate programs. Over the past 10 years, this trend has only increased (Table 7).

Table 7. The percentage of foreign citizens who studied at the postgraduate centers of Russian higher education institutions of various types, $\%$

\begin{tabular}{|l|c|c|}
\hline The departmental affiliation / The type of ownership of a higher education institution & The year 2003/2004 & The year 2013/2014 \\
\hline Federal (the higher education institutions of the Ministry of Education and Science of Russia) & 60.3 & 74.6 \\
\hline Of the Subjects of Federation and municipal & 0.4 & 0.8 \\
\hline Of other ministries and departments & 36.1 & 23.5 \\
\hline Non-state education establishments & 3.3 & 1.2 \\
\hline Total & 100.0 & 100.0 \\
\hline
\end{tabular}

The total number of Russian higher education institutions, in which the foreign postgraduate students studied during the academic year 2013/2014, is 349, of which 182 higher education institutions are subordinated to the Ministry of Education and Science, 26-to the Ministry of Health, 30-to the Ministry of Agriculture, 17-to the Ministry of Culture, 9-to the Ministry of Transport, 23-to other 13 ministries, departments, and establishments; 4 higher education institutions-to regions and municipalities; and 24 higher education institutions were private (including 4 religious institutions).

Among the higher education institutions of the Ministry of Education and Science of Russia, the majority of the foreign postgraduate students study in the People's Friendship University of Russia (534 persons), in the Pushkin State Russian Language Institute (85 persons), and in the Bauman Moscow State Technical University (79 persons); among the higher education institutions of the Ministry of Health-in the I.M. Sechenov First Moscow State Medical University (45 persons); among the higher education institutions of the Ministry of Agriculture-in the Russian State Agrarian 
University - Timiryazev Moscow Agricultural Academy (48 persons); among the higher education institutions of the Ministry of Culture-in the Tchaikovsky Moscow State Conservatory (59 persons); among the higher education institutions of the Ministry of Transport-in the Moscow State University of Railway Engineering (29 persons); among the higher education institutions of the Ministry of Sport, Tourism, and Youth Policy -in the Russian State University of Physical Education, Sport, Youth, and Tourism (34 persons); among the higher education institutions of the Ministry of Foreign Affairs-in the MGIMO (34 persons); among the higher education institutions of the Government of the Russian Federation-in the Lomonosov Moscow State University (233 persons), and the Saint Petersburg State University (170 persons); among the private higher education institutions-in the National Institute of Business (11 persons) and in the Omsk Humanitarian Academy (10 persons); among the higher education institutions of the religious profile-in the Moscow Orthodox Theological Academy (8 persons).

An average of 13 postgraduate students falls to the share of one postgraduate center of a higher education university (to which the foreign postgraduate students can be enrolled). In the academic year 2013/2014, the foreigners amounted to $3.8 \%$ among all the Russian postgraduate students (including the full-time and part-time forms of academic training).

In Russia, there are 17 higher education institutions that have more than 50 postgraduate students, and almost all of them are located in Moscow and Saint Petersburg (Table 8). These higher educational institutions enroll $45.6 \%$ of all foreign postgraduate students.

Table 8. The Russian higher education institutions - the leaders in the number of foreign full-time postgraduate students in the academic year of 2013/2014.

\begin{tabular}{|l|c|}
\hline The higher education institution & The number of foreign postgraduate students \\
\hline 1. The People's Friendship University of Russia & 534 \\
\hline 2. The Lomonosov Moscow State University & 233 \\
\hline 3. The Saint Petersburg State University & 170 \\
\hline 4. The Pushkin State Russian Language Institute & 85 \\
\hline 5. The Bauman Moscow State Technical University & 81 \\
\hline 6. The Kazan (Volga region) Federal University & 79 \\
\hline 7-9. The Irkutsk State Technical University & 76 \\
\hline 7-9. The Moscow State Pedagogical University & 76 \\
\hline 7-9. The National Research University "MPEl" & 76 \\
\hline 10. The National Research Tomsk Polytechnic University & 74 \\
\hline 11. The Voronezh State University & 65 \\
\hline 12. The Moscow State University of Economics, Statistics and Informatics & 62 \\
\hline 13. The Herzen State Pedagogical University of Russia & 60 \\
\hline 14-15. The Tchaikovsky Moscow State Conservatory & 59 \\
\hline 14-15. The Saint Petersburg State University of Economics & 59 \\
\hline 16. The Moscow Automobile and Road Construction University & 53 \\
\hline 17. The Saint Petersburg State Polytechnic University & 51 \\
\hline Total & 1,883 \\
\hline
\end{tabular}

The attention is drawn to the reduction (as compared to the Soviet period) in the number of foreign postgraduate students in the Lomonosov Moscow State University - the "flagship" of the Russian education (in the late 1980s, the contingent of the foreign postgraduate students in the Moscow State University exceeded 350 persons), and the "stagnation" of this indicator over the last decade (Table 9).

Table 9. The number of the foreign postgraduate students who studied in the Lomonosov Moscow State University during the academic years of 2003/2004 - 2013/2014.

\begin{tabular}{|l|c|c|c|c|c|c|}
\hline Years & $2003 / 2004$ & $2005 / 2006$ & $2007 / 2008$ & $2009 / 2010$ & $2011 / 2012$ & $2013 / 2014$ \\
\hline The number of foreign postgraduate students & 218 & 226 & 221 & 208 & 217 & 233 \\
\hline
\end{tabular}

The ratio of majors, in which the foreign citizens are trained in the postgraduate centers of the higher education universities, has also changed. For example, while in the Soviet times, every third postgraduate student studied technical sciences, and every fifth—natural science and exact sciences, in recent years, only every fifth postgraduate student 
chooses the technical profile, and every tenth-natural science and exact sciences. The share of the postgraduate students studying medicine, agriculture, and the Russian language has decreased twice, whereas the share of the postgraduate students specialized in humanities and social sciences, culture, and especially pedagogics has increased (due to the interest thereto from the side of the representatives of China studying the corresponding Soviet or Russian experience); the postgraduate students preparing their theses in computer sciences have appeared (every twentieth), etc. (Figure 6).

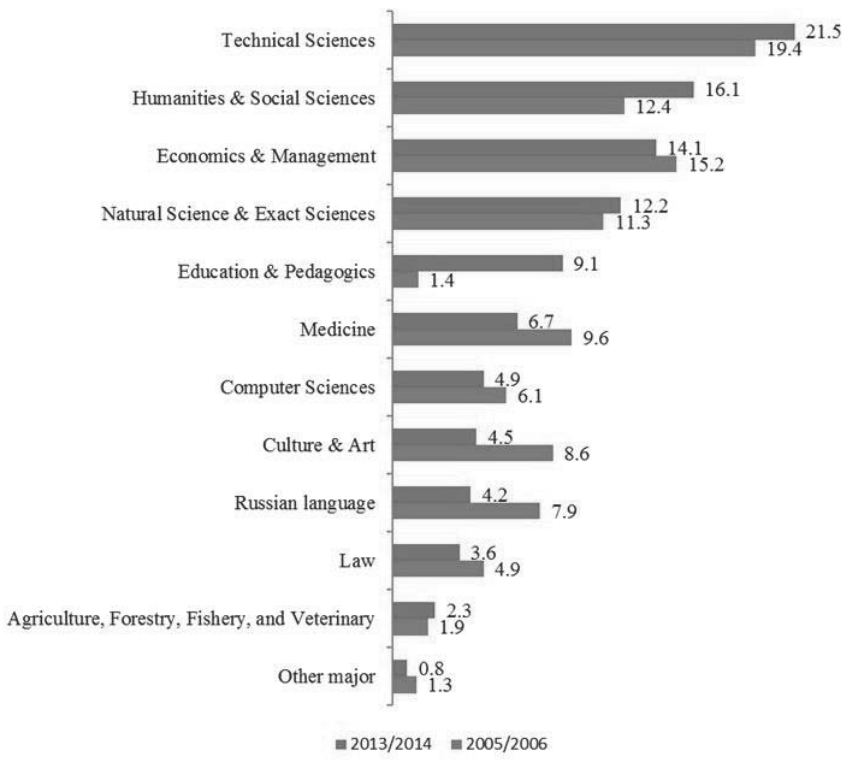

Figure 6. The majors studied by foreign postgraduate students of Russian higher education institutions in the academic years of 2005/2006 and 2013/14, \%

As compared to the Soviet period, the number of foreign postgraduate students, who miss the deadlines in providing their theses for defense, has increased. Therefore, these foreign postgraduate students are often left at higher education institutions for one more year, whereas such staying is formally considered to be the fellowship period, so that they could complete their thesis research.

It should be noted that the training of highly qualified personnel (in the master's and postgraduate/doctoral programs) is the main brand of any higher education institution in the international education market. In the majority of countries leading in the international education, foreign citizens aim to study primarily in the so-called graduate and postgraduate programs (i.e. above the bachelor's degree).

\section{Conclusions}

Foreign citizens, especially from the countries outside the CIS and Baltic regions, prefer to study at Russian higher education institutions in the so-called pre-graduate programs (the bachelor's degree level and the actually equated to it specialist's degree) and then, in order to complete the tertiary level of education, to leave for foreign higher education institutions entering the master's and doctorate course programs. This is also associated with another important fact-the non-recognition of the Russian diplomas of higher education in many countries including those, where the foreign students would like to work. In this case, they are forced to confirm the Russian diploma by passing a special examination, or to complete their education in the postgraduate programs at national or foreign higher education institutions.

Due to the significant inertia of the national educational system, its transition to the two-level system (of the bachelor's and master's degree courses) in accordance with the Bologna Agreement, which was signed by Russia 12 
years ago, proceeds very slow; and this seems to be one of the reasons why Russia is behind the leading countries in the international market of education (the USA, Great Britain, Australia, Germany, France, and Canada), since many foreigners are first of all seeking to receive abroad (including Russia) the generally recognized international academic degrees.

The training at Russian higher education institutions in the doctoral course programs (the relict form of training scientific personnel) is of little demand among foreigners: in the academic year 2013/2014, this program enrolled only 81 students, mostly from the CIS countries and Mongolia (10 years ago, in the year 2003/2004, there were 104 students). The measure of bringing the Russian education programs into compliance with the international standards is the decision on giving the postgraduate course of study the status of the third level of higher education since January 1, 2015.

Based on the assumption that the average annual growth rates among foreign postgraduate students attending the full-time courses of study at Russian higher education institutions will be maintained until 2030, we can predict that in fifteen years, the number of foreigners studying at Russian postgraduate centers will reach 11.3 thousand people. With the total number of all foreign students (the participants of the preparatory courses, students, trainees, interns, registrars, etc.) equal to 570,000 people, the percentage of postgraduate students in the academic year 2029/2030 will make $2 \%$, that is, by 2.5 times lower than in the academic year 2000/2001, when it amounted to $5.0 \%$. By the year 2030, the majority of foreign postgraduate students will come from the former Soviet republics. However, due to the rapid development of e-learning technologies, Russian higher education institutions will increase the percentage of off-campus foreign postgraduate students from this group of countries.

\section{Acknowledgements}

The article was prepared on the basis of the results of the scientific analysis performed according to the Agreement with the Ministry of Education and Science of the Russian Federation on Subventions No. 03.573.21.0004 of September 22, 2014 (Code "2014-03-573-0029-002").

\section{References}

Aref'ev A.L. (2004). Podgotovka kadrov vysshei kvalifikatsii v rossiiskikh vuzakh [Training of Highly Qualified Personnel at Russian Higher Education Institutions]. Moscow: Center for Social Forecasting [in Russian].

Belkov, S.A., Kliachko, T.L., Polushkina, E.A., \& Krasnova, G.AP. (2011). Eksport obrazovatel'nykh uslug. Analiz upravlencheskikh reshenii [Exporting the educational services. Analysis of the management decisions]. Moscow: Russian Academy of National Economy and Public Administration [in Russian].

Belov, V.A. (2000). Podgotovka kadrov dlia zarubezhnykh stran v sovetskikh vuzakh [Training of personnel for the foreign countries in Soviet higher educational institutions]. Moscow: EKON [in Russian].

Belov, V.A. (2003). Obuchenie inostrannykh grazhdan v Rossii: Istoricheskii opyt, problemy, perspektivy [Training of foreign citizens in Russia: historical experience, problems, and prospects]. Moscow: Peoples' Friendship University of Russia [in Russian].

Eksport rossiiskikh obrazovatel'nykh uslug [Export of the Russian Educational Services] (2015). Statsticheskii sbornik - Statistical Digest, 5. Moscow: Center for Sociological Research [in Russian].

Fiull'zak, M. (2001). Ozdorovlenie ili raspad? K voprosu o sud'be rossiiskoi nauki [Recovery or Breakup? To the Question on the Fate of the Russian Science]. Rossiia i sovremennyi mir - Russia and the Modern World, 3 [in Russian].

Golubev, V.K., Gorchakov, G.E., Myshelov, V.P., \& Khomiakov, A.M. (1994). Uroki proshlogo v sovremennom rakurse [Lessons from the past in a modern perspective]. Vysshee obrazovanie v Rossii - Higher Education in Russia, 4. 90-96. [in Russian].

Izmerenie reitingov universitetov. Mezhdunarodnyi i rossiiskii opyt [Measuring the university rankings. International and Russian experience] (2014). Moscow: Center for Social Forecasting [in Russian].

L'essentiel des chifres clees (2014. pp. 9). Paris: Agence CampusFrance.

Modernizatsiia rossiiskogo obrazovaniia: problemy i perspektivy [Modernization of the Russian education: problems and prospects] (2010). Moscow: RAS Institute of Sociology [in Russian].

Obuchenie inostrannykh grazhdan v vysshikh uchebnykh zavedeniiakh Rossiiskoi Federatsii [Training of foreign citizens at higher education institutions of the Russian Federation] (2015). Statisticheskii sbornik - Statistical Digest, 12. Moscow: Center for Sociological Research [in Russian].

OECD. Education at a Glance 2014: OECD Indicators. OECD Publishing (2014). Retrieved from: http://dx.doi.org/10.1787/eag-2014-en.

Opendoors. Report on International Educational Exchange. (2014). New York: Institute of International Education.

Podgotovka kadrov spetsialistov dlia zarubezhnykh stran v Rossii: sostoianie i perspektivy razvitiia [Training of personnel for the foreign countries in Russia: conditions and prospects of development] (1999). Informatsionno-analiticheskie i metodicheskie materialy Information-analytical and methodological materials. Moscow: The Ministry of Education of the Russian Federation [in Russian].

Rossiia v tsifrakh [Russia in Figures]. (2014). Kratkii statisticheskii sbornik - Brief Statistical Digest. Moscow: Federal State Statistics Service [in Russian]. 
Rossiiskoe obrazovanie dlia inostrannykh grazhdan [The Russian Education for the Foreign Citizens] (2010). Moscow: GNII ITT «Informika» [in Russian].

Sheregi, F.E., Dmitriev, N.M., \& Aref'ev, A.L. (2002). Nauchno-pedagogicheskii potentsial i eksport rossiiskikh obrazovatel'nykh uslug rossiiskikh vuzov [The Scientific and Pedagogical Potential and the Export of the Russian Educational Services of the Russian Higher Education Institutions]. Moscow: Center for Social Forecasting [in Russian].

Student Mobility in Higher Education among APEC Member Economies (2015). Assessing the Current State of Data and Processes. New York: Institute of International Education.

Tkach, G.F., \& Filippov V.M. (2014). Organizatsionno-pravovye i prakticheskie mekhanizmy obespecheniia akademicheskoi mobil'nosti i rasshireniia ekspotra obrazovatel'nykh uslug [The Organizational, Legal, and Practical Mechanisms to Ensure Academic Mobility and Expand the Export of Educational Services]. Moscow: Peoples' Friendship University of Russia [in Russian].

Wissenschaft weltoffen (2014). Retrieved from: http://www.wissenschaft-weltoffen.de/. 